Naturally, a good proportion of the work has been concerned with powdered or broken vegetable drugs, and Prof. Edman claimed that his method of examination is sometimes more convenient than normal ones. The drug is strongly heated until the bulk of the tissues is completely burned away; the characteristic appearance of the mineral skeletons of the cell walls and the cell contents is then revealed. The method, however, has several other important applications, especially in criminal proceedings involving suspected arson. Further, the examination of prehistoric materials by this method has been of some assistance to archæologists. Thus, the examination of the charred vegetable matter in a Chinese clay-sheard, about five thousand years old, showed it to consist mainly of the remains of the leaf blades of Oryza sativa, the same plant used to-day for the production of rice. In the same way, fragments of cereals, medicinal herbs, etc., have been identified in the intestines of Egyptian mummies. Prof. Edman has also examined the ash pictures of about 375 related plant species in relation to their phylogeny and taxonomy and has published many original articles on this subject in the botanical literature. $\mathrm{He}$ concludes that extensive silicification of the cell wall is associated with primitive characters.

J. W. Fairbairn

\section{OBSERVATIONS AT THE ROYAL OBSERVATORY, GREENWICH}

T

HE observations made at the Royal Observatory, Greenwich, during 1937 in astronomy, magnetism and meteorology, under the direction of $\operatorname{Sir} \mathrm{H}$. Spencer Jones, have been published in a single volume (pp. $A 62+B 21+C 200+D 66+E 46+40$. London :

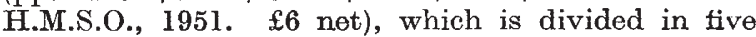
sections, $A-E$, as follows: meridian astronomy, equatorial observations, photo-heliographic observations, magnetic observations and meteorological observations.

The first section includes work on the transit circle and on the time service; in the former are the results of regular observations of the sun, moon, major planets and minor planets Juno, Ceres, Pallas and Vesta, and in the latter is given a short account of the new equipment and advances in the technique since the publication of the "Time Service Results" in 1936. The section on equatorial observations contains a table on the observations of double stars made at the Observatory which includes not only all pairs observed during 1937 but also all previously unpublished measures of earlier years. A systematic difference was found for close pairs between the results of the filar micrometer and of the comparison image micrometer (brought into use towards the end of 1937), and the table indicates which instrument was used.

The second section, on photo-heliographic observations, is by far the largest of the five sections. The positions and areas of sunspots and faculæ for each day during the year 1937 is the first of seven tables in this section, the photographs being taken at the Royal Observatories of Greenwich or of the Cape, and at the Kodaikanal Observatory (a negative transparency for November 3 was supplied by the Mt. Wilson Observatory to fill a gap in the series). The other tables are : a general catalogue of groups of sunspots for 1937 ; ledgers of areas and positions of groups of sunspots (recurrent groups and nonrecurrent groups); total areas of sunspots and faculæ for each day; mean areas of sunspots and faculæ for each rotation and for the year ; mean heliographic latitude of spots for each rotation and for the year ; and observations of solar flocculi made with the spectrohelioscope.

The introduction to the section on magnetic observations describes the magnetic station at Abinger, with its instruments, methods of observation, magnetic reductions and arrangement of results ; these results are listed in fifteen tables, and there are notes for each month of 1937 which briefly summarize the magnetic conditions exhibited by the traces of declination and horizontal and vertical intensity during the year. Finally, a description of the instruments and the meteorological reductions is given in the section on meteorological observations; several changes were made in the 1934 volume as regards the notation for clouds and weather, this being done to bring the symbols into general accordance with those in use at the British Meteorological Office.

All the above-mentioned work by the Royal Observatory, Greenwich, was continued during 1938, and an account of it has now been published; the volume is similar in all respects to that for 1937. Another series of Greenwich observations which has at last been published is Vol. 2 of "Observations of Colour Temperatures of Stars : Relative Gradients" (pp. 115; London : H.M.S.O., 1952; 25s. net) ; this volume covers the years 1933-38 and is a sequel to the observations of 1926-32, published in Vol. 1.

\section{UNITED STATES NATIONAL ACADEMY OF SCIENCES}

A $\mathrm{T}$ the annual general meeting of the National A Academy of Sciences, held in Washington, D.C., during April 27-29, the following officers, new members and foreign associates were elected.

Vice-President : George W. Corner, director, Department of Embryology, Carnegie Institution of Washington, Baltimore, Maryland, for a four-year term.

New Members of Council: Edwin B. Wilson, professor of vital statistics, Harvard School of Public Health, Boston; and Hugh L. Dryden, National Advisory Committee for Aeronautics, Washington, D.C.

New Members : L. V. Ahlfors, professor of mathematics, Harvard University; P. Bailey, professor of neurology and neuro-surgery, University of Illinois School of Medicine; H. A. Barker, microbiologist, University of California, Berkeley; V. H. Benioff, professor of geophysics, California Institute of Technology ; J. H. Bodine, professor of zoology, University of Iowa; L. Brillouin, director of electronics education, International Business Machines Corporation, New York; M. J. Buerger, professor of mineralogy and crystallography, Massachusetts Institute of Technology; H. E. Carter, professor of biochemistry, University of Illinois ; D. M. Dennison, professor of physics, University of Michigan; J. P. Den Hartog, professor of mechanical engineering, Massachusetts Institute of Technology; J. W. M. DuMond, ptofessor of physics, California Institute of Technology ; C. Eckart, director of the Marine Physical Laboratory, University of California, San Diego; 
R. Emerson, research professor in botany, University of Illinois ; J. F. Enders, chief, Division of Infectious Diseases, Children's Hospital, Boston ; P. J. Flory, professor of chemistry, Cornell University; $G$. Gamow, professor of theoretical physics, George Washington University, Washington, D.C.; V. Hamburger, professor of zoology, Washington University, St. Louis ; C. E. Hille, professor of mathematics, Yale University ; J. O. Hirschfelder, professor of chemistry, University of Wisconsin; J. G. Horsfall, director, Connecticut Agricultural Experiment Station, New Haven; E. H. Land, president, Polaroid Corporation, Cambridge, Mass. ; D. P. C. Lloyd, member, Rockefeller Institute for Medical Research, New York; H. W. Nissen, associate director, Yerkes Laboratories of Primate Biology, Orange Park; D. Rittenberg, associate professor of biochemistry, Columbia University; J. F. Schairer, physical chemist, Geophysical Laboratory, Carnegie Institution, Washington, D.C. ; T'. Shedlovsky, member, Rockefeller Institute for Medical Research, New York ; J. C. Street, professor of physics, Harvard University ; M. Tishler, director, Development Research Department, Merck and Company, Inc., Rahway, N.J.; H. G. Wood, head of the Department of Biochemistry, Western Reserve University; and R. B. Woodward, professor of chemistry, Harvard University.

Foreign Associates : J. H. Oort, director, Leyden Observatory; and Wilder Penfield, professor of neurology and neurosurgery, McGill University, and director, Montreal Neurological Institute, Montreal.

\section{KOSSUTH PRIZES IN HUNGARY FOR 1953}

$\mathrm{W}$ INNERS of the 1953 Kossuth Prizes in Hungary, which are given for outstanding work during the past year, have recently been announced. These Prizes carry monetary awards of various amounts ( 1,000 forints is approximately $\mathfrak{E} 3)$, and those given for scientific, technological or medical work include the following. A Prize of 50,000 forints to Frederick Riesz, president of the Mathematical Section of the Hungarian Academy of Sciences, for his book entitled "Lesson of Functional Analysis", written in conjunction with B. Nagy, in which theories are developed that are of great importance in the development of mathematics. Prizes of 20,000 forints to : B. Nagy, correspondent member of the Hungarian Academy of Sciences, for his part in the joint work with F. Riesz, mentioned above; F. Ratkovszky, for work on the electrification of the country and for making a 'diabolo-transformer'; K. Novobatzky, professor of theoretical physies in the University of Budapest, for research on the quantum theory; J. Egerváry, for work in applied mathematies on the theory of differential equations, particularly in the development of a method for computing the critical limit of rotations of rotors in turbo-generators ; Z. Csürös, academician, for results achieved in the study of heterogeneous catalysis; A. Ábrahám, correspondent member of the Academy, for research of the nerve tissues, based on the teachings of Pavlov; Z. Gyulai, correspondent member of the Academy, for research work on the boundary layers of crystals and solutions, and for the production of artificial quartz crystals; V. Keilwert, chemical engineer at the Láng engineering factory for directing the planning of the Debrecne ponicillin factory; J. Proszt, professor in the Inorganic Chemistry Institute, for pioneering research in the preparation of organic silicon compounds ; L. Kulin, specialist in children's diseases, for results achieved in curing tuberculosis in babies ; G. Bárczi, director of the Budapest Therapeutical Teachers Training College, for results achieved in basing Hungarian medical teaching and education on the natural sciences and for applying Pavlovian theories; $\mathrm{J}$. Kollonitsch, departmental head of the Medicine Industry Research Institute, for medical research and work in the pharmaceutical industry, particularly in the new preparation of 'Treomycin' for the treatment of whooping cough, typhoid and dysentery.

Prizes of 10,000 forints to: P. K. Károly, correspondent member of the Academy, for his text-book entitled "The Factory Science of Electrical Machines", and for research ; L. Verebély, professor at the Technical University, for his handbook entitled "Transmission of Electrical Energy", and for work on electrification; J. Urbanek, director of the Central Research Laboratory of the Electrical Industry, for his text-book entitled "Introduction to the Technical Science of Theoretical Electricity" and for his new method of cooling turbo-generators by refrigeration; S. Müller, correspondent member of the Academy, for work in organic chemistry in connexion with the industrial production of synthetic materials; A. Romwalter, university professor, for research in coal chemistry; K. Rauss, professor at the Pécs Medical Science University, for research into children's diseases and dysentery inoculation; L. Fuchs, university dean, for work on the theory of structural algebra.

\section{HYDRATION OF METAL CATIONS}

\section{By DR. E. GLUECKAUF and G. P. KITT} Atomic Energy Research Establishment, Harwell, Berks

$\mathrm{M}$ EASUREMENTS have been made by the isopiestic method of the water content of hydrogen and metal polystyrene sulphonates at different water vapour pressures and at two different temperatures, using concentrated sulphuric acid solutions as vapour pressure standards. This permits of a calculation both of water-activities (see curves $A$ and $B$ ) and of the differential heats of hydration $\bar{H}$ of the ions (curve $C$ ). The polystyrene sulphonates of monovalent ions show in this respect great similarity to the behaviour of strong $1: 1$ electrolytes such as, for example, lithium chloride or perchloric acid and, as has been shown previously ${ }^{1,2}$, can be considered as concentrated solutions of electrolyte in their swelling water. Indeed, the trend of $\boldsymbol{H}$ for the hydrogen polystyrene sulphonate (curve $C$ ) is very similar to that of concentrated sulphuric acid ${ }^{3}$ in the range where the latter may be regarded as a monovalent acid, $\mathrm{H} \cdot \mathrm{SO}_{4} \mathrm{H}$ (see curve $D$ ). For a study of concentrated solutions the polystyrene sulphonates have a great advantage over most aqueous solutions: they can be concentrated without crystallization to any desired. strength (100 molal and above) and thus provide information on the interaction of water with all kinds 